\title{
The Role of the Property Tax in Urban Land Speculation
}

\author{
Bedane Shata Gemeda \\ Addis Ababa University
}

\begin{abstract}
This article reports the results of an extensive survey of owners of undeveloped land in and outside the Shashemene City. After identifying several distinct owner types, the authors demonstrate that changes in ownership, as well as in the character and use of land, begin more than twenty years before the rural countryside is actually converted to urban use. These findings have important implications for the design and implementation of policies attempting to control or direct urban growth. In particular, a simple dynamic model that explains the optimum length of time to hold a parcel of land from a market was developed and its properties were analyzed both qualitatively and numerically. One finding is that the speculator will hold the land for the marginal period only if the difference between present net rates of return exceeds the difference between discounted expected per cent returns. On the other hand, if land speculators held land for one year, property tax increased by 0.000079 birr per year, which is inappropriate methods to control land speculation .
\end{abstract}

Keywords: Land speculation; Model; Property tax; Speculators; Sprawling.

DOI: $10.7176 / \mathrm{JEES} / 9-1-05$

\section{Introduction}

Much academic attention has been devoted recently to describing and analyzing the causes, nature, and economic implications of urban sprawl (Aurand, 2007). More specifically, most research in this area has focused on the costs and causes of non-compact forms of urban development. Perhaps the most costly, and certainly the most often attacked form of sprawl, is the leapfrog development - a subdivision separated from the periphery of the urbanized area by some amount of land which is either completely vacant or unused for urban purposes. Abstracting from motives which are irrational in an economic sense, and from topographical considerations, a major cause of this inefficient development is speculation in land values which, for purposes of this paper, will be defined as occurring if land is withheld from the market for economic reasons by a rational (a profit maximizing) individual (Bayer, Geisser and Roberts,2011,p.3).

The specific objectives of this analysis are twofold: (a) to develop a relatively uncomplicated land speculation model from which the optimum time period (from the landowner's viewpoint) for withholding a parcel of land from the market (b) to determine the relative effects of the property tax

\section{Materials and Methodology}

For the study both case study method and economic assumption have been applied to fulfill the requirement of the objectives. In case study approach, two urban villages were selected through purposive non-random sampling technique method and the sampled villages were Awasho and Dida Boke. The reason why these villages were selected is that it is one of the fastest-growing urban areas in the city both demographically and spatially. The amount of land demanded for different urban development purposes was increasing every year in the selected villages. In response to the growing demands for land, the government, developers, home builders and private Organizations are taking large tracts of land from villages and kept vacant without developing. As a result Urban sprawl and leapfrogging were emerged, which increase the cost of infrastructure. The standardized questionnaire survey has been carried out at the household level in the sampled villages while checklist was used for data collection from group discussion, key informants and relevant institutions. Informal group discussion was made to get information regarding different issues relevant to the study.

For analyzing collected data EXCELL and STATA software were used for tabulation, analysis and graphic presentation. Arc GIS 9.3 and Arc View 3.2software were also exercised for mapping analysis. To develop land speculation model economic assumptions are used. The development of a model to explain the actions of an urban land speculator necessitates a statement of temporal rather than static equilibrium conditions. This problem is analogous to the classic examples of how long should the tree be permitted to grow or how many years should the wine be permitted to age. In each of these two examples an additional year of waiting brings an increase in the quality (and therefore in the value) of the product, but it also means a higher opportunity cost to the holder. An early statement of marginal conditions for the optimal length of investment (attributed to W.S.Jevons) is that a "ripening" asset should be held until the discounted rate of increase in value is equated with the opportunity cost (per cent return)( Bahl,163). If one identifies the costs and returns associated with speculating in urban land, it should be possible to develop a similar set of optimality conditions.

More specifically, the model developed here is an extension of Gaffney's technique for analyzing the effects of time indivisibility.' The central problem in Gaffney's paper is to define the conditions under which a 
rational individual will continue to add to his land holdings. Applying an equimarginal analysis, Gaffney develops what the terms a "dynamic equilibrium equation which shows that an individual will add units of land to his holdings until the rate of return plus the expected future rate of return on the last unit just yields him his interest rate.

The optimality conditions are developed in terms of the ratio of the difference between the rate of return on the land and an opportunity cost for the current period, to the discounted difference between these rates for the aggregate of all future periods. These conditions can be much more easily explained when discrete time periods are considered. In formulating the model this way, it is implied that the landowner faces the sell or hold decision at the beginning of each period and makes his decision on the basis of what he expects in terms of net benefits for the coming period, and his evaluation of aggregated, discounted net benefits in all future periods.

\section{Results and discussion}

\subsection{Developing Land Speculation Model}

In order to develop a model to explain the optimum length of time to hold a parcel of land, assume the value of the land to be increasing at a decreasing rate, i.e., $\frac{d v}{d t}>0$ and $d^{2} / 2 \frac{2}{d},<0$ where $\frac{d v}{d t}$ represents the rate of increase in market value. The traditional incremental reasoning of economic theory suggests that, with perfect knowledge, the speculator will hold the land an additional period only if the increase in market value is great enough to compensate him for the additional cost incurred during that period. Abstracting from risk considerations, these costs include the property tax and the opportunity cost, i.e. the amount which could have been earned by investing an amount equivalent to the current market value of the land in the best alternative investment.'

Symbolically, this condition may be expressed as:

(1) $R_{t}=\mathrm{P}+\mathrm{i} v_{t-1}$

Where:

$R_{t}=$ increase in the value of the land during the $t^{\text {th }}$ year,

$P_{t}=$ amount of the property tax for the $t^{t h}$ year,

$\mathrm{i}=$ rate of return which could be earned on the best possible alternative investment and,

$V_{t-1}=$ market value of the land at the beginning of the $t^{t h}$ year.

However, since property taxes are fully deductible for federal income tax purposes, the landowner does not consider the entire amount $P_{t}$, an incremental cost, specifically only an amount $(1-\mathrm{S}) P_{t}$ is borne by the speculator, where $\mathbf{S}$ represents his marginal personal income tax rate. Thus, from (1) it may be seen that the optimal time for selling the land occurs when:

$$
\frac{\left[R_{\left.t-(1-s) P_{t}\right]}\right.}{V_{t-1}}
$$

The left side of Equation (la) (hereafter referred to as $r$ ) is the net rate of return to the landowner, or alternatively, may be thought of as his indifferent rate of interest, i.e., that market rate of return at which he will be indifferent between holding the land for an additional period or selling now and re investing the return, Conversely, if $\mathbf{i}$ is expected to exceed $\mathbf{r}$ in the $t^{t h}$ period, the landowner will be acting rationally if he sells.

This relatively simple statement of optimality conditions from the viewpoint of the speculator is based on two assumptions. First, the landowner must be certain that he may re-evaluate his position at the beginning of each time period. Thus, his expectations for future growth in the value of the land beyond the first year are disregarded. Second, the value of the parameters of the system are estimated with certainty (though it would be possible to assign probabilities to both sides of the equation).

A second and more realistic case may be developed in which the landholder feels that he must consider not only his position in the next period, but also his expected returns and costs for the following periods. Under these conditions, the optimality condition in (la) must be amended to reflect: (a) the expectations of the landowner for future increases in the value of the land, (b) the estimate of the landowner of the expected future return from an alternative investment, and (c) the marginal cost of time. Applying these modifications, the equilibrium statement becomes:

$$
R_{t+} \sum_{j=t+1}^{n} \quad R_{j-(1-s)} P_{j} /\left(1+\widehat{l}^{j}=(1-\mathrm{s}) P_{t}+i v_{t-1}-\sum_{j=t-1}^{n} \frac{l_{j}}{(1+i)^{j}}\right.
$$

Where:

$R_{j}=$ the dollar increment in the value of the land in the $j^{\text {th }}$ year, and

$l_{j}=$ the dollar return which could be earned in the $j^{t h}$ year by selling the land and re investing the proceeds in the best alternative investment.

Rearranging the terms in Equation (2) and dividing through by $v_{t-1}$ yields:

$$
\frac{R_{t(1-s) P_{t}}}{V_{t-1}}-\mathrm{i}=\frac{\sum_{j=1+1}^{n} l_{j} /(1+i)^{j}-\sum_{j=t+1}^{n}\left[R_{j-(1 . s) P_{j] / 1+i} j}\right.}{V_{t-1}}
$$


(2b)

$$
\mathbf{r}-\mathbf{i}=\mathbf{i}^{*}-\mathbf{r}^{*}
$$

Where:

$\mathbf{r}-\mathbf{i}=$ difference between the net rate of return on the land and the land owner's interest rate (in year $\mathrm{t}$ ), and

$\mathbf{i}^{*}-\mathbf{r} *=$ difference between the discounted expected percent return on an alternative investment, and on the land (over $n$ years)

Therefore, if the equilibrium condition is stated in terms of actual and expected per cent returns, one concludes that the speculator will hold the land for the marginal period only if the difference between present net rates of return exceeds the difference between discounted expected per cent returns.

To use a numerical example from data obtained from study area, assume a speculator is certain of a return of ten per cent (net of property taxes) if he holds a parcel of land for the coming period, and further, he is aware that if he holds the land, he must forego a return in that period of six per cent on an alternative investment. After choosing an appropriate time horizon ( $n$ periods), the speculator estimates a discounted net return on the land of 20 per cent and a comparable rate for the alternative of 24 per cent. Since $(r-i) /\left(i^{*}-r^{*}\right)>1$, the land should be held for the $t^{\text {th }}$ period. The landholder may then reevaluate his position at the beginning of each succeeding period by the same criterion. It is implicitly assumed in this modified statement of the optimality condition that the landowner sees his position at the beginning of each period as one of selling now or holding the land until time period $n$ (the number of years in his time horizon).

3.2. Policy implication of the model

The above analysis may be generalized in the following functional relationship

$$
t_{o}=\mathrm{f}\left[\mathrm{i}, \mathrm{i}^{*}, \mathrm{r}, \mathrm{r}^{*}, \mathrm{~s}, \mathrm{n}, \mathrm{g}, \mathrm{p}\right]
$$

Where:

$t_{o}=$ optimum time period for holding land,

$\mathrm{r}=$ net rate of return on the land,

$\mathrm{r}^{*}=$ discounted expected per cent return on the land,

$\mathrm{i}=$ the individual's interest rate,

$i^{*}=$ discounted expected per cent return on an alternative investment,

$\mathrm{P}=$ the property tax.

If the effect of changes in each variable in the system on the optimum time period for holding the land $\left(t_{o}\right)$ could be identified, it would be a simple matter to evaluate the relative effectiveness of alternative policies which are followed by fiscal and physical planners in attempting to constrain sprawl.

The cost of capital, or opportunity cost (i), varies among individuals with their ability and capacity to invest and the quantity and quality of their opportunities. While Gaffney's i represents " . . the rate of interest at which the individual discounts future values," the discount factor for land in the present paper includes a risk premium, i.e., $\hat{\imath}=\mathrm{i}+\mathrm{g}$, thus, $R_{j}$ will be discounted at a higher rate than $l_{j}$. The length of the speculators time horizon (n) will depend in part on his forecast of the intensity and regularity of the demand for urban land. For example, if the landowner suspects that a current flurry of building activity will leave the community "overbuilt" in a couple of years, his time horizon will be shorter than if he expects population growth to be sufficient to support the higher level of building activity for a longer period of time. Given the length of the speculator's time horizon, an increase in either $\mathrm{i}$ or $\mathrm{g}$ will shorten the optimal period for holding the land. Likewise, an increase in the property tax or a reduction in $\mathrm{r}$ or $\mathrm{r}^{*}$ will accomplish the same result.

\subsection{Model specification}

In order to quantify the relationship between the magnitude of optimum time period for holding land by speculators, net rate of return on the land, discounted expected per cent return on the land, discounted expected per cent return on an alternative investment, property tax and market value of land, a multiple linear regression model (Eq. (1)) is employed.

$$
\mathrm{y}=\beta 0+\beta 1 \mathrm{x} 1+\beta 2 \mathrm{x} 2+\ldots+\beta \mathrm{kxk}+\varepsilon
$$

In the equation, $\mathrm{y}$ is the dependent variable, that is, the magnitude of optimum time period for holding land by speculators; $\beta^{\prime} \mathrm{s}$ are the regression coefficients; $\beta 0$ is constant; $\varepsilon$ is the error term. The meanings and definitions of the variables are presented in Table 1. (See appendix) 


\subsubsection{Output of Multiple linear regression analysis}

\begin{tabular}{|c|l|l|l|}
\hline Source & SS & df & MS \\
\hline Model & 82.0383502 & 5 & 16.40767 \\
Residual & 461649759 & 4 & .11541244 \\
\hline Total & 82.5 & 9 & 9.16666667 \\
\hline
\end{tabular}
Number of obs $=10$
Prob $>\mathrm{F}=0.001$
R-squared $=0.9944$
Adj R-squared $=0.987$
Root MSE $=.33972$

\begin{tabular}{|l|l|l|l|l|ll|}
\hline Period & Coef. & Std.Err & $\mathrm{t}$ & $\mathrm{P}>/ \mathrm{t} /$ & {$[95 \%$ Conf.Interval] } \\
\hline tax & 0.00079 & .0000201 & 3.93 & 0.017 & .0000232 & .0001348 \\
\hline price & -.0000118 & $3.09 \mathrm{e}-06$ & -3.83 & 0.019 & -.0000204 & $-3.23 \mathrm{e}-06$ \\
\hline rate & .000014 & $4.31 \mathrm{e}-06$ & 3.24 & 0.032 & $2.02 \mathrm{e}-06$ & .0000259 \\
\hline discount & $1.87 \mathrm{e}-06$ & $3.73 \mathrm{e}-07$ & 5.01 & 0.007 & $8.33 \mathrm{e}-07$ & $2.91 \mathrm{e}-06$ \\
\hline cost & $3.32 \mathrm{e}-06$ & $3.02 \mathrm{e}-06$ & 1.10 & 0.334 & $-5.08 \mathrm{e}-06$ & .0000117 \\
\hline cons & 3.726409 & .779801 & 4.78 & 0.009 & 1.561334 & 5.891483 \\
\hline
\end{tabular}

In this regression output, $\mathrm{R} 2=0.9944$. Adjusted $\mathrm{R} 2=0.9874$, which means that the independent variables, explains $98.74 \%$ of the variability of the dependent, in the population. Adjusted R2 is also an estimate of the effect size, which at 0.9874 (98.74\%), is indicative of a medium effect size, according to Cohen's (1988) classification. However, normally it is R2 not the adjusted R2 that is reported in results. A multiple linear regression established that net rate of return on the land, discounted expected per cent return on the land, discounted expected per cent return on an alternative investment, property tax and market value of land were statistically significant in predicting dependent variable $(98.74 \%$ dependent variable explained by independent variables).(see appendix)

The regression equation was:

$\mathrm{Y}=00007 \times \operatorname{tax}+(-.0000118) \times$ price $+0.000014 \times$ rate $+1.87 \mathrm{e}-06 \times$ discount $+3.32 \mathrm{e}-06 \times \operatorname{cost}+3.726409$ or $\mathrm{y}=000079 x_{1}-0.0000118 x_{2}+0.000014 x_{3}+1.87 \mathrm{e}-06 x_{4}+3.32 \mathrm{e}-06 x_{5}+3.726409$.

Where:

$\mathrm{Y}=$ optimum holding period of land by land speculators

$x_{1}=$ property tax

$x_{2}=$ market value of land

$x_{3}=$ net rate of return on the land

$x_{4}=$ discounted expected per cent return on the land

$x_{5}=$ discounted expected per cent return on an alternative investment

Using this estimated regression model, we can find the predicted value of $y$ for specific values of $x 1, x 2, x 3$, $\mathrm{x} 4$ or $\mathrm{x} 5$. If the holding period of land by speculators are increased by one year, the value of tax in a given year is increased by 0.000079 birr by keeping the others variable constant. Therefore, one might offer the hypothesis that manipulation of the property tax is in general not an effective method of discouraging speculation in urban land in study area.

\section{Conclusion}

If local government policies of constraint are to be directed toward the speculator, it appears that the effect must come either directly through an increase in the property tax or indirectly through an increase in the degree of uncertainty associated with holding the land. The evaluation of the relative effect of these alternatives in shortening the optimum time period would necessarily involve a comparison of the property tax and discount factor elasticities.Even in the simple model where expectations are not relevant (See Equation la), increases in the property tax would not appear to be a strong deterent to urban sprawl and land speculation. In summary, there would appear to be two ways in which the optimal number of time periods for speculation might be shortened by action of the local government: (a) an increase in the risk factor, i.e., an increase in the difference between $\hat{\imath}$ and $i,(b)$ an increase in property taxes. Since these factors might be influenced either directly or indirectly by government policy, the discussion below is a qualitative examination of the potential for using each to constrain land speculation. Consequently, $\Delta \mathrm{R}=\$ 10,000$ and $\Delta \mathrm{P}=\$ 420$. Therefore, the increased cost (tax) to the speculator would appear to be a relatively small proportion of the increase in the value of the land. In general, property tax is inappropriate method to control land speculation.

\section{References}

A. G. Aurand, "Is Smart Growth for Low-Income House- holds: A Study of the Impact of Four Smart Growth Principles on the Supply of Affordable Housing," Doctoral Thesis, University of Pittsburgh, Pittsburgh, $2007,451 \mathrm{p}$. 
Bayer, Patrick, Christopher Geissler, and James W. Roberts. 2011. "Speculators and Middlemen: The Role of Intermediaries in the Housing Market." National Bureau of Economic Research Working Paper 16784. http://www.nber.org/papers/w16784 (accessed September 12, 2017).

Bahl, R.W. A Bluegrass Leapfrog. Lexington: Bureau of Business Research, University of Kentucky, 1963.

Blalock, Hubert M. Social Statistics. Toronto: McGraw Hill 1960.

Burchfield, M., Overman, H., Puga, D., Turner, M. A. (2006) Causes of sprawl: a portrait from space. Quarterly Journal of Economics, 2: 587-633.

Cox, Kevin R. 1997.Governance, urban regime analysis, and the politics of local economic development. In Reconstructing urban regime theory: Regulating urban politics in a global economy, ed. Mickey Lauria, 99121. Thousand Oaks, CA: Sage.

Fox , W. S. and J.H. Soper. "The Distribution of Some Trees and Shrubs of the Carolinian Zone of Southern Ontario." Part 1 in Transactions of the Royal Canadian Institute 29(1952): 65-84.

H. James Brown , Robyn Swaim Phillips \& Neal A. Roberts (1981) Land Markets at the Urban Fringe New Insights for Policy Makers, Journal of the American Planning Association, 47:2, 131-144, DOI:10.1080/01944368108977098

Irwin, E. G., Bockstael, N. E. (2007) .The evolution of urban sprawl: evidence of spatial heterogeneity and increasing land fragmentation. Proceedings of National Academy of Sciences USA, 104: 20672-20677.

Lessinger, J. (1962) Urban sprawl and speculation in suburban land. Journal of the American Institute of Planners, 28: 159-169.

Lindeman, B. 1976. Anatomy of land speculation. Journal of the American Institute of Planners 40, April: 142152.

Logan, John R., and Harvey L. Molotch. 2007. Urban fortunes: The political economy of place. $2 \mathrm{nd}$ ed. Berkeley, CA: University of California Press.

Mills, D. E. (1981) Growth, speculation and sprawl in a monocentric city. Journal of Urban Economics, 10: 201226.

Mahlon Burwell, “Maidstone and Rochester", forty chains, 1824. W. Chewett's copy of Burwell's plan. Ao $613.7 \mathrm{~m} 28$.

Ohls, J. C., Pines, D. (1975) .Urban development and economic efficiency. Land Economics, 51: 224-234

Ottensmann, J. R. (1977) Urban sprawl, land values, and the density of development. Land Economics, 53: $389-400$

Peiser, R. (1989) Density and urban sprawl. Land Economics, 65: 193-204.

Smith, L. B. 1976. The Ontario land speculation tax: an analysis of an unearned increment land tax. Land Economics 52, February:1-12.

Stone, Clarence N. 1987. The study of the politics of urban development. In The politics of urban development, ed. Clarence N. Stone and Heywood T. Sanders, 3-22. Lawrence, KS: University of Kansas.

Stanley, Benjamin W. 2014."Local Property Ownership, Municipal Policy, and Sustainable Urban Development in Phoenix, AZ." Community Development Journals. http://cdj.oxfordjo

urnals.org/content/early/2014/12/09/cdj.bsu062.full?keytype $=$ ref\&ijkey=qCR0tOlViSt0i4s (accessed December 12, 2016). doi:10.1093/cdj/bsu062

Yin, R.K. 2003 .Case study research, design and methods. Sage Publications, Thousand Oaks, CA.

\section{Appendix}

Table 1

1. Variable specification

\begin{tabular}{|l|l|}
\hline Variable & Meaning \\
\hline Property tax & The amount of money collected by tax collectors \\
\hline Opportunity cost & Alternative investment \\
\hline Holding period & The optimal periods of land held by the speculators \\
\hline Market value of land & The actual price of land \\
\hline Net return & Net profit after investment \\
\hline Discounted return & $\begin{array}{l}\text { The amount of money obtained after discounting future value money } \\
\text { obtained }\end{array}$ \\
\hline
\end{tabular}

